\title{
RESPON PERTUMBUHAN DAN PRODUKSI TANAMAN GAMBAS (Luffa acutangula L. Roxb) TERHADAP PEMBERIAN Trichoderma sp. DAN BEBERAPA DOSIS PUPUK KANDANG KOTORAN SAPI
}

\author{
Dian Novita1)" ${ }^{1 *}$, Taufik Syamsuddin'1), Agustinus Giawa2) \\ 1) Dosen Program Studi Agroteknologi Fakultas Pertanian Uiversitas Tamansiswa Palembang \\ 2) Alumni Program Studi Agroteknologi Fakultas Pertanian Uiversitas Tamansiswa Palembang \\ ")email: dian_argamakmur@yahoo.co.id
}

\begin{abstract}
This study aims to find out the response of gambas plant growth and production (Luffa acutangula L. Roxb) to the administration of Trichoderma sp. and several doses of cow manure manure. This research was conducted in the farmer's garden of Jalan Siaran, Lorong Pelita, Sako District, South Sumatra Province in May to July 2020. This study using Randomized Design Group (RAK) Factorial consists of two treatment factors with 8 combinations of treatment and 3 repeats, so there are 24 maps. Trichoderma treatment sp. Consists of T0 control (without Trichoderma sp.), T1 uses Trichoderma sp. (15 g/plant). Cow manure treatment consists of K0 control (without cow manure), K1 cow manure 20 tons / ha or (4 kg / plot), K2 cow manure 30 tons / ha or $(6 \mathrm{~kg} /$ plot), and K3 cow manure 40 tons / ha or ( $8 \mathrm{~kg} / \mathrm{plot})$. Based on the results of the research that has been done, it can be concluded that: Giving Trichoderma sp. give the best influence on the number of crops of average fruit length (cm), and fruit production / ha (ton). The provision of cow manure manure 30 tons / ha gives the best influence on the length of plants $(\mathrm{cm})$, the number of crops of average fruit length $(\mathrm{cm})$, fruit diameter $(\mathrm{cm})$, and fruit production / ha (tons). Interaction between the administration of Trichoderma sp. and manure manure 30 tons / ha gives the best influence on the number of crops and fruit production / ha (tons).
\end{abstract}

Keyword: Luffa acutungula L. Roxb, Trichoderma, cow manure

\section{ABSTRAK}

Penelitian ini bertujuan untuk mengetahui respon pertumbuhan dan produksi tanaman gambas (Luffa acutangula L. Roxb) terhadap pemberian Trichoderma sp. dan beberapa dosis pupuk kandang kotoran sapi. Penelitian ini dilaksanakan di Kebun petani Jalan Siaran, Lorong Pelita, Kecamatan Sako, Provinsi Sumatera Selatan pada bulan Mei sampai dengan bulan Juli 2020. Penelitian ini menggunakan Rancangan Acak Kelompok (RAK) Faktorial terdiri dari dua faktor perlakuan dengan 8 kombinasi perlakuan dan 3 kali ulangan, sehingga terdapat 24 petakan. Perlakuan Trichoderma sp. Terdiri dari To kontrol (tanpa Trichoderma sp.), T1 menggunkan Trichoderma sp. (15 g/tanaman). Perlakuan pupuk kandang kotoran sapi terdiri dari $\mathrm{K}_{0}$ kontrol (tanpa pupuk kandang kotoran sapi), $\mathrm{K}_{1}$ pupuk kandang kotoran sapi 20 ton/ha atau (4 kg/petak), $\mathrm{K}_{2}$ pupuk kandang kotoran sapi 30 ton/ha atau (6 kg/petak), dan $\mathrm{K}_{3}$ pupuk kandang kotoran sapi 40 ton/ha atau $(8 \mathrm{~kg} /$ petak). Berdasarkan hasil penelitian yang telah dilakukan, maka dapat disimpulkan bahwa pemberian Trichoderma sp. memberikan pengaruh terbaik terhadap jumlah buah pertanaman panjang buah rata-rata $(\mathrm{cm})$, dan produksi buah/ha (ton). Pemberian pupuk kandang kotoran sapi 30 ton/ha memberikan pengaruh terbaik terhadap panjang tanaman $(\mathrm{cm})$, jumlah buah pertanaman panjang buah rata-rata $(\mathrm{cm})$, diameter buah $(\mathrm{cm})$, dan produksi buah/ha (ton). Interaksi antara pemberian Trichoderma sp. dan pupuk kandang kotoran sapi 30 ton/ha memberikan pengaruh terbaik terhadap jumlah buah pertanaman dan produksi buah/ha (ton).

Kata kunci: Gambas, tricoderma, pupuk kotoran sapi

\section{PENDAHULUAN}

Gambas (Luffa acutangula L. Roxb), dikenal juga dengan nama lain oyong. Tanaman ini termasuk dalam famili Cucurbitaceae, berasal dari India, namun telah beradaptasi baik di Asia Tenggara termasuk Indonesia. Tanaman ini merupakan tanaman memanjat/merambat. Produksi 
tanaman gambas selama kurun waktu tahun 2013-2019 mengalami peningkatan rata-rata $35,60 \%$ dari 12,25 juta ton pada tahun 2013 , dan meningkat menjadi 17,85 juta ton pada tahun 2019 (BPS,2019). Mineral yang dominan pada gambas adalah kalium, fosfor, magnesium, dan kalsium. Gambas juga mengandung beberapa unsur mikro antara lain besi, dan seng. Mineral yang terdapat dalam gambas berupa besi 0,36 $\mathrm{mg} / 100 \mathrm{~g}, \quad$ fosfor $31 \mathrm{mg} / 100 \mathrm{~g}$, kalsium 14 $\mathrm{mg} / 100 \mathrm{~g}$, magnesium $20 \mathrm{mg} / 100$, dan seng $0,17 \mathrm{mg} / 100 \mathrm{~g}$ (Dandge, et al., 2012).

Pupuk berperan penting dalam mencukupi kebutuhan hara atau nutrisi bagi tanaman. Pupuk kandang kotoran sapi sangat berperan sebagai sumber makanan bagi bahan organisme tanah, pupuk kandang kotoran sapi akan meningkatkan jumlah organisme tanah. Tanah menjadi gembur sehingga produksi tanaman meningkat (Sukamto, 2007). Pemupukan akan efektif dan efisien apabila diberikan pada saat yang tepat dengan cara yang benar yaitu dosis optimum dan jenis pupuk sesuai dengan kebutuhan unsur hara tanaman (Setiawan, 2008). Dosis pupuk kandang kotoran sapi dan pupuk buatan secara tepat, mengalami kesulitan. Hal ini disebabkan karena lokasi, jenis tanah dan kandungan unsur hara nya berbeda. Perbedaan pertumbuhan lebih ditentukan oleh dosis aplikasi, kualitas tanah yang terbentuk, dari penambahan dosis pupuk kandang tersebut yang berbeda (Hardjowigeno, 2007).

Pupuk kandang kotoran sapi memiliki banyak keunggulan dibandingkan dengan pupuk sintesis.Sumarni et al., (2010) menyatakan bahwa takaran dosis pupuk kandang kotoran sapi 30 ton/ha akan meningkatkan produksi dan pertumbuhan tanaman gambas. Satu ekor sapi dewasa dapat menghasilkan 23,59 kg kotoran tiap harinya. Pupuk kandang kotoran sapi mengandung unsur $\mathrm{N}, \mathrm{P}, \mathrm{K}$, juga sejumlah unsur hara mikro, seperti Fe, Zn, Bo, Mn, Cu, dan Mo. Jadi dapat dikatakan bahwa pupuk kandang kotoran sapi ini dapat dianggap sebagai pupuk alternatif untuk mempertahankan produksi tanaman (Djazuli dan Ismunadji,1983).

Salah satu cara manipulasi lahan secara biologi adalah pemanfaatan mikroorganisme. Cendawan Trichoderma sp. merupakan mikroorganisme tanah bersifat saprofit. Trichoderma sp. secara

alami menyerang cendawan patogen dan bersifat menguntungkan antara fungsi tular tanah dengan akar-akar tanaman. Spesies Trichoderma sp. disamping sebagai organisme pengurai juga berfungsi sebagai agens hayati (Wahyuno et al., 2009). Menurut (Poulton et al., 2011) cendawan Trichoderma sp. membantu tanaman induk menyerap unsur hara tertentu terutama fosfat. Fosfat adalah salah satu unsur hara makro yang diperoleh dengan bantuan cendawan Trichoderma sp. dan ditransfer ketanaman (Rosewarne et al., 1999).

Purwantisari (2009) mengatakan bahwa Trichoderma sp. merupakan cendawan parasit yang dapat menyerang dan mengambil nutrisi dari cendawan lain. Jamur Trichoderma sp. dapat menjadi hiperparasit pada beberapa jenis jamur penyebab penyakit tanaman dan pertumbuhannya sangat cepat (Triyanto dan Sumantri, 2003). Hasil penelitian Anis dan Gayuh, (2014) menunjukkan bahwa pemberian Trichoderma sp. 15-20 gram/lubang tanam akan mempercepat perakaran, serta dengan pertumbuhan dan produksi tanaman gambas.

Disamping sebagai pengendali hayati, Trichoderma sp. memberikan pengaruh positif terhadap perakaran tanaman, pertumbuhan tanaman, dan hasil produksi tanaman dengan memberikan dosis yang tepat. Hasil penelitian Esrita et al., (2011) menunjukkan bahwa dosis Trichderma sp. 15g/tanaman cukup baik untuk mendukung pertumbuhan dan hasil tanaman.

Berdasarkan uraian diatas, maka perlu dilakukan penelitian mengenai respon pertumbuhan dan produksi tanaman gambas terhadap pemberian Trichoderma sp. dan beberapa dosis pupuk kandang kotoran sapi.

\section{Tujuan Penelitian}

Tujuan dari penelitian ini adalah Untuk mengetahui respon pertumbuhan dan produksi tanaman gambas terhadap pemberian Trichoderma $s p$. , beberapa dosis pupuk kandang kotoran sapi, dan interaksinya.

\section{METODE PENELITIAN}

Penelitian ini direncanakan dilaksanakan di kebun petani Jalan Siaran, Lorong Petita, Kecamatan Sako, Provinsi Sumatera Selatan akan dimulai pada bulan Mei sampai dengan bulan Juli 2020.

Bahan yang digunakan pada penelitian ini adalah benih tanaman oyong Azura F1, trichoderma $s p$, pupuk kandang kotoran sapi, insektisida, 
pestisida, dolomit, dan pupuk NPK. Sedangkan alat yang digunakan pada penelitian ini adalah cangkul, parang, ember, tali rafia, timbangan, gunting, meteran, papan perlakuan, dan gembor.

Penelitian menggunakan Rancangan Acak Lengkap dengan 2 faktor perlakuan dan diulang sebanyak 4 kali.

1. Perlakuan Trichoderma sp:

$\mathrm{T}_{0}$ : Kontrol (tanpa Trichoderma sp.)

$\mathrm{T}_{1}$ : Trichoderma sp (15 g/lubang)

2. Perlakuan pupuk kandang kotoran sapi:

$\mathrm{K}_{0}$ : Kontrol (Tanpa pupuk kotoran sapi)

$\mathrm{K}_{1}$ : pupuk kandang kotoran sapi 20 ton/ha

$\mathrm{K}_{2}$ : pupuk kandang kotoran sapi 30 ton/ha)

$\mathrm{K}_{3}$ : pupuk kandang kotoran sapi 40 ton/ha

\section{Prosedur Kerja}

\section{Pengolahan Lahan}

Lahan terlebih dahulu dibersihkan dari gulma dengan menggunakan parang. Selanjutnya tanah dicangkul dan digemburkan dengan kedalaman kurang lebih $20 \mathrm{~cm}$ kemudian dibiarkan terkena sinar matahari selama 2 minggu. Setelah itu dibuat petakan dengan ukuran $180 \times 200 \mathrm{~cm}$, tinggi petakan $20 \mathrm{~cm}$ sebanyak 24 petak, dan jarak antara petakan $50 \mathrm{~cm}$ serta jarak antara ulangan $80 \mathrm{~cm}$. Setelah petakan dibuat, tanah di campur rata dengan pemberian dolomit dilakukan 7-10 hari sebelum pemberian pupuk dasar.

\section{Pemupukan}

Pemupukan dilakukan dengan memberikan pupuk dasar yaitu pupuk NPK, dengan dosis 250 $\mathrm{kg} / \mathrm{ha}$ atau $300 \mathrm{~g} /$ petak, pupuk dasar ini dilakukan 1 minggu sebelum tanam. Setelah dilakukan pemberian pupuk dasar dilanjutkan dengan pemberian pupuk perlakuan yaitu pupuk kandang kotoran sapi. Diberikan sesuai dengan perlakuan yaitu $\mathrm{K}_{1} 20$ ton/ha atau $7,2 \mathrm{~kg} /$ petak, $\mathrm{K}_{2} 30$ ton/ha atau $10,8 \mathrm{~kg} /$ petak, $\mathrm{K}_{3} 40$ ton/ha atau $14,4 \mathrm{~kg} /$ petak. Pemberian pupuk perlakuan dilakukan 3 hari sebelum tanam.

\section{Penanaman}

Penanaman benih tanaman oyong dilakukan dengan cara ditugal. Benih tanaman oyong ditanam sebanyak 2 benih per lubangtanam. Jarak tanam yang digunakan $60 \times 50 \mathrm{~cm}$, sehingga terdapat12 lubang/petak. Setiap lubang tanam diberikan perlakuan trichoderma sp. yaitu 15 gram/lubang.

\section{Pemeliharaan}

Pemeliharaan yang dilakukan meliputi penyiraman, penyulaman, pemasangan lanjaran, penyiangan, pemupukan serta pengendalian hama dan penyakit.

\section{Panen}

Buah oyong bisa dipanen pada usia 40-45 hst. Buah dipanen ketika masih muda yaitu ketika kulit buah masih berwarna hijau segar, kulit tidak mengkilat, kulit buah masih lunak, mudah dipatahkan, dan belum berserat. Untuk penelitian pemanenan hasil buah tanaman oyong dilakukan 1-7 kali panen.

\section{Peubah yang Diamati}

Peubah yang diamati dalam penelitian ini meliputi, Panjang Tanaman (cm), Jumlah Buah Per Tanaman, Panjang Buah rata-rata (cm), Berat Buah Per Tanaman $(\mathrm{kg})$, Diameter buah $(\mathrm{cm})$, Produksi buah/ha $(\mathrm{kg})$

\section{HASIL DAN PEMBAHASAN}

Hasil

Di bawah ini adalah hasil analisis sidik ragam terhadap semua parameter yang diamati disajikan pada Tabel 1

Tabel 1. Hasil Analisis Keragaman (Uji F) terhadap parameter yang diamati

\begin{tabular}{lcccc}
\hline \multirow{2}{*}{ Parameter } & \multicolumn{3}{c}{ F hitung } & \multirow{2}{*}{ KK $(\%)$} \\
\cline { 2 - 4 } & Trichoderma & Kotoran sapi & Interaksi \\
\hline Panjang tanaman $(\mathrm{cm})$ & $2,10^{\text {tn }}$ & $8,88^{* *}$ & $1,72^{\text {tn }}$ & 6,47 \\
Jumlah buah per tanaman & $80,62^{* *}$ & $45,64^{* *}$ & $5,35^{* *}$ & 3,42 \\
Panjang buah rata-rata $(\mathrm{cm})$ & $7,09^{*}$ & $8,97^{* *}$ & $1,80^{\text {tn }}$ & 3,68 \\
Berat buah per tanaman $(\mathrm{g})$ & $3,89^{\text {tn }}$ & $2,64^{\text {tn }}$ & $0,13^{\text {tn }}$ & 7,20 \\
Diameter buah (cm) & $2,04^{\text {tn }}$ & $5,43^{* *}$ & $1,14^{\text {tn }}$ & 1,75 \\
Produksi buah/ha (ton) & $8,34^{* *}$ & $6,09^{* *}$ & $3,27^{*}$ & 9,87 \\
\hline F tabel 0,05 & 4,32 & 3,07 & 3,07 & \\
\multicolumn{1}{c}{0,01} & 8,02 & 4,87 & 4,87 & \\
\hline
\end{tabular}


Keterangan :

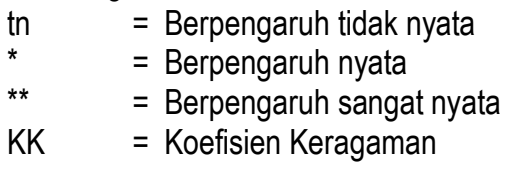

Berdasarkan hasil sidik ragam menunjukkan bahwa perlakuanTrichodema $s p$. memberikan pengaruh berbeda sangat nyata pada parameter jumlah buah pertanaman. Sedangkan pada parameter panjang tanaman, panjang buah rata-rata, berat buah per tanaman, diameter buah, dan produksi buah/ha, menunjukkan perlakuan Trichoderma sp. memberikan pengaruh yang tidak nyata.

Perlakuan pupuk kandang kotoran sapi menunjukkan pengaruh yang sangat nyata terhadap panjang tanaman, jumlah buah per tanaman, diameter buah, dan produksi buah/ha.Sedangkan pada parameter, panjang buah rata-rata, dan berat buah per tanaman menunjukkan pengaruh yang tidak nyata.

Interaksi antara perlakuan Trichoderma sp. dan pupuk kandang kotoran sapi menunjukkan pengaruh yang sangat nyata terhadap jumlah buah per tanaman dan menunjukkan pengaruh yang nyata terhadap produksi buah/ha. Sedangkan pada parameter panjang tanaman, panjang buah ratarata, berat buah per tanaman dan diameter buah menunjukkan interaksi yang tidak nyata.

\section{Panjang tanaman $(\mathrm{cm})$}

Data hasil pengamatan memperlihatkan bahwa perlakuan $\mathrm{K}_{2}$ merupakan tanaman terpanjang mencapai $573,50 \mathrm{~cm}$ dan tanaman terpendek pada perlakuan $\mathrm{K}_{1}$ dengan panjang tanaman $494,50 \mathrm{~cm}$.

Tabel 2. Hasil uji lanjut perlakuan pupuk kandang kotoran sapi $(\mathrm{K})$ terhadap rerata panjang tanaman $(\mathrm{cm})$ gambas.

\begin{tabular}{ccc}
\hline Perlakuan & $\begin{array}{c}\text { Panjang } \\
\text { tanaman }\end{array}$ & $\begin{array}{c}\text { BNJ 1\% } \\
(59,53)\end{array}$ \\
\hline $\mathrm{K}_{2}$ & 573,50 & $\mathrm{~A}$ \\
$\mathrm{~K}_{3}$ & 517,25 & $\mathrm{AB}$ \\
$\mathrm{K}_{0}$ & 502,88 & $\mathrm{~B}$ \\
$\mathrm{~K}_{1}$ & 494,50 & $\mathrm{~B}$ \\
\hline Keterangan: & $\begin{array}{c}\text { Angka-angka yang diikuti oleh huruf } \\
\text { yang sama pada kolom yang sama }\end{array}$ \\
& menunjukkan perbedaan yang tidak \\
& nyata pada taraf uji 1\%.
\end{tabular}

Hasil uji lanjut menunjukkan bahwa perlakuan $\mathrm{K}_{2}$ berbeda tidak nyata dengan perlakuan $\mathrm{K}_{3}$ tetapi berbeda sangat nyata dengan perlakuan lainnya. Perlakuan $\mathrm{K}_{3}$ tidak berbeda nyata dengan perlakuan $\mathrm{K}_{0}$ dan $\mathrm{K}_{1}$. Perlakuan $\mathrm{K}_{1}$ berbeda sangat nyata dengan perlakuan lainnya.

\section{Jumlah Buah per Tanaman}

Data hasil pengamatan memperlihatkan bahwa perlakuan $T_{1} K_{2}$ merupakan tanaman yang memiliki jumlah buah per tanaman terbanyak mencapai 12,70 buah dan tanaman yang memiliki jumlah buah per tanaman terendah dicapai oleh perlakuan $\mathrm{T}_{0} \mathrm{~K}_{0}$ yaitu 9,05 buah.

Tabel 3. Hasil uji lanjut perlakuanTrichoderma sp. (T) terhadap jumlah buah gambas.

\begin{tabular}{ccc}
\hline Perlakuan & Jumlah buah & $\begin{array}{c}\text { BNJ 1 \% } \\
(0,37)\end{array}$ \\
\hline $\mathrm{T}_{1}$ & 11,28 & $\mathrm{~A}$ \\
$\mathrm{~T}_{0}$ & 10,11 & $\mathrm{~B}$ \\
\hline
\end{tabular}

Keterangan: Angka-angka yang diikuti oleh huruf yang sama pada kolom yang sama menunjukkan perbedaan yang tidak nyata pada taraf uji $1 \%$.

Hasil uji lanjut menunjukkan bahwa perlakuan $T_{1}$ berbeda sangat nyata dengan perlakuan $T_{0}$ Perlakuan $T_{0}$ berbeda sangat nyata dengan perlakuan $T_{1}$.

Tabel 4. Hasil uji lanjut perlakuan pupuk kandang kotoran sapi $(\mathrm{K})$ terhadap rerata jumlah buah gambas.

\begin{tabular}{ccc}
\hline Perlakuan & Jumlah buah & $\begin{array}{c}\text { BNJ 1\% } \\
(0,64)\end{array}$ \\
\hline $\mathrm{K}_{2}$ & 11,68 & $\mathrm{~A}$ \\
$\mathrm{~K}_{3}$ & 10,85 & $\mathrm{~B}$ \\
$\mathrm{~K}_{1}$ & 10,70 & $\mathrm{~B}$ \\
$\mathrm{~K}_{0}$ & 9,55 & $\mathrm{C}$ \\
\hline
\end{tabular}

Keterangan: Angka-angka yang diikuti oleh huruf yang sama pada kolom yang sama menunjukkan perbedaan yang tidak nyata pada taraf uji $1 \%$.

Hasil uji lanjut menunjukkan bahwa perlakuan $\mathrm{K}_{2}$ berbeda sangat nyata dengan perlakuan $\mathrm{K}_{3}$ Perlakuan $\mathrm{K}_{3}$ berbeda tidak nyata dengan perlakuan $\mathrm{K}_{1}$, tetapi berbeda sangat nyata dengan perlakuan $\mathrm{K}_{0}$. Perlakuan $\mathrm{K}_{0}$ berbeda sangat nyata dengan perlakuan lainnya. 
Tabel 5. Hasil uji interaksi antara perlakuan Trichoderma sp (T) dan pupuk kandang kotoran sapi $(\mathrm{K})$ terhadap rerata jumlah buah pertanaman gambas.

\begin{tabular}{ccc}
\hline Perlakuan & $\begin{array}{c}\text { Jumlah buah } \\
\text { per tanaman }\end{array}$ & $\begin{array}{c}\text { BNJ 1 \% } \\
(0,89)\end{array}$ \\
\hline $\mathrm{T}_{1} \mathrm{~K}_{2}$ & 12,70 & $\mathrm{~A}$ \\
$\mathrm{~T}_{1} \mathrm{~K}_{3}$ & 11,25 & $\mathrm{AB}$ \\
$\mathrm{T}_{1} \mathrm{~K}_{1}$ & 11,10 & $\mathrm{BC}$ \\
$\mathrm{T}_{0} \mathrm{~K}_{2}$ & 10,65 & $\mathrm{BCD}$ \\
$\mathrm{T}_{0} \mathrm{~K}_{3}$ & 10,45 & $\mathrm{BCDE}$ \\
$\mathrm{T}_{0} \mathrm{~K}_{1}$ & 10,30 & $\mathrm{CDEF}$ \\
$\mathrm{T}_{1} \mathrm{~K}_{0}$ & 10,05 & $\mathrm{DEF}$ \\
$\mathrm{T}_{0} \mathrm{~K}_{0}$ & 9,05 & $\mathrm{G}$ \\
\hline Keterangan: & Angka-angka yang diikuti oleh huruf \\
& yang sama pada kolom yang sama \\
& menunjukkan perbedaan yang tidak \\
& nyata pada taraf uji 1\%.
\end{tabular}

Hasil uji lanjut menunjukkan bahwa perlakuan $T_{1} K_{2}$ berbeda tidak nyata dengan perlakuan $T_{1} K_{3}$, tetapi berbeda sangat nyata dengan perlakuan lainnya.Perlakuan $\mathrm{T}_{1} \mathrm{~K}_{3}$ berbeda sangat nyata dengan perlakuan $T_{1} K_{1}$. Antar perlakuan $T_{1} K_{1} T_{0} K_{2}$, $\mathrm{T}_{0} \mathrm{~K}_{3}$ berbeda tidak nyata, tetapi berbeda sangat nyata dengan perlakuan $\mathrm{T}_{0} \mathrm{~K}_{1}$.Perlakuan $\mathrm{T}_{0} \mathrm{~K}_{1}$ berbeda sangat nyata dengan perlakuan $T_{1} K_{0}$.Perlakuan $T_{1} K_{0}$ berbeda sangat nyata dengan perlakuan $\mathrm{T}_{0} \mathrm{~K}_{0}$.Perlakuan $\mathrm{T}_{0} \mathrm{~K}_{0}$ berbeda sangat nyata dengan perlakuan lainnya.

\section{Diameter buah (cm)}

Data hasil pengamatan memperlihatkan bahwa perlakuan $\mathrm{K}_{2}$ merupakan tanaman yang memiliki diameter buah terbesar mencapai $3,86 \mathrm{~cm}$ dan tanaman yang memiliki diameter buah terkecil dicapai oleh perlakuan $\mathrm{K}_{0}$ yaitu $3,74 \mathrm{~cm}$.

Tabel 6. Hasil uji lanjut perlakuan pupuk kandang kotoran sapi $(\mathrm{K})$ terhadap rerata diameter buah $(\mathrm{cm})$ gambas.

\begin{tabular}{ccc}
\hline Perlakuan & $\begin{array}{c}\text { Diameter buah } \\
(\mathrm{cm})\end{array}$ & $\begin{array}{c}\text { BNJ 1 \% } \\
(0,12)\end{array}$ \\
\hline $\mathrm{K}_{2}$ & 3,86 & $\mathrm{~A}$ \\
$\mathrm{~K}_{1}$ & 3,84 & $\mathrm{AB}$ \\
$\mathrm{K}_{3}$ & 3,83 & $\mathrm{AB}$ \\
$\mathrm{K}_{0}$ & 3,74 & $\mathrm{~B}$ \\
\hline Keterangan: & Angka-angka yang diikuti oleh huruf \\
& yang sama pada kolom yang sama \\
& menunjukkan perbedaan yang tidak \\
& nyata pada taraf uji 1\%.
\end{tabular}

Hasil uji lanjut menunjukkan bahwa perlakuan $\mathrm{K}_{2}$ berbeda tidak nyata dengan perlakuan $\mathrm{K}_{1}$ dan $\mathrm{K}_{3}$, tetapi berbeda sangat nyata dengan perlakuan $\mathrm{K}_{0}$ PerlakuanK $K_{0}$ berbeda sangat nyata dengan perlakuan lainnya

\section{Produksi buah/ha (ton)}

Data hasil pengamatan memperlihatkan bahwa perlakuan $T_{1} K_{2}$ merupakan tanaman yang memiliki produksi buah/ha terberat mencapai 5,39 ton,dan tanaman yang memiliki produksi buah/ha terendah dicapai oleh perlakuan $\mathrm{T}_{0} \mathrm{~K}_{0}$ yaitu 3,78 ton.

Tabel 7. Hasil uji lanjut perlakuan pupuk kandang kotoran sapi $(\mathrm{K})$ terhadap rerata produksi buah/ha pada tanaman gambas.

\begin{tabular}{ccc}
\hline Perlakuan & $\begin{array}{c}\text { Produksi } \\
\text { Buah/Ha (ton) }\end{array}$ & $\begin{array}{c}\mathrm{BNJ} \text { 1\% } \\
(0,76)\end{array}$ \\
\hline $\mathrm{K}_{2}$ & 4,84 & $\mathrm{~A}$ \\
$\mathrm{~K}_{1}$ & 4,44 & $\mathrm{AB}$ \\
$\mathrm{K}_{3}$ & 4,38 & $\mathrm{AB}$ \\
$\mathrm{K}_{0}$ & 3,92 & $\mathrm{~B}$ \\
\hline
\end{tabular}

Keterangan: Angka-angka yang diikuti oleh huruf yang sama pada kolom yang sama menunjukkan perbedaan yang tidak nyata pada taraf uji $1 \%$.

Hasil uji lanjut menunjukkan bahwa perlakuan $\mathrm{K}_{2}$ tidak berbeda nyata dengan perlakuan $\mathrm{K}_{1}$ dan $\mathrm{K}_{3}$, tetapi berbeda sangat nyata dengan perlakuan $\mathrm{K}_{0}$ Perlakuan $\mathrm{K}_{0}$ berbeda sangat nyata terhadap perlakuan lainnya.

Tabel 8. Hasil uji interaksi antara perlakuan Trichoderma sp.(T) dan pupuk kandang kotoran sapi (K) terhadap produksi buah/ha (ton) gambas.

\begin{tabular}{ccc}
\hline Perlakuan & $\begin{array}{c}\text { Produksi } \\
\text { buah/ha (ton) }\end{array}$ & $\begin{array}{c}\text { BNJ } 5 \% \\
(0,67)\end{array}$ \\
\hline $\mathrm{T}_{1} \mathrm{~K}_{2}$ & 5,39 & $\mathrm{a}$ \\
$\mathrm{T}_{1} \mathrm{~K}_{3}$ & 4,68 & $\mathrm{~b}$ \\
$\mathrm{~T}_{0} \mathrm{~K}_{1}$ & 4,54 & $\mathrm{bc}$ \\
$\mathrm{T}_{1} \mathrm{~K}_{1}$ & 4,33 & $\mathrm{bcd}$ \\
$\mathrm{T}_{0} \mathrm{~K}_{2}$ & 4,29 & $\mathrm{bcd}$ \\
$\mathrm{T}_{0} \mathrm{~K}_{3}$ & 4,08 & $\mathrm{bcd}$ \\
$\mathrm{T}_{1} \mathrm{~K}_{0}$ & 4,06 & $\mathrm{bcd}$ \\
$\mathrm{T}_{0} \mathrm{~K}_{0}$ & 3,78 & $\mathrm{~d}$ \\
\hline
\end{tabular}

Keterangan: Angka-angka yang diikuti oleh huruf yang sama pada kolom yang sama menunjukkan perbedaan yang tidak nyata pada taraf uji $5 \%$. 
Hasil uji lanjut menunjukkan bahwa perlakuan $\mathrm{T}_{1} \mathrm{~K}_{2}$ berbeda nyata dengan perlakuan $\mathrm{T}_{1} \mathrm{~K}_{3}$. Antar perlakuan $T_{0} K_{1}, T_{1} K_{1}, T_{0} K_{2}, T_{0} K_{3}$ dan $T_{1} K_{0}$ berbeda tidak nyata, tetapi berbeda nyata dengan perlakuan $\mathrm{T}_{0} \mathrm{~K}_{0}$.Perlakuan $\mathrm{T}_{0} \mathrm{~K}_{0}$ berbeda nyata dengan perlakuan lainnya.

\section{Pembahasan}

Berdasarkan analisis sidik ragam pada penelitian menunjukkan bahwa interaksi antara respon pertumbuhan dan produksi tanaman gambas terhadap pemberian Trichoderma sp. dan beberapa dosis pupuk kandang kotoran sapi berpengaruh nyata terhadap jumlah buah per tanaman dan produksi buah/ha.

Respon pertumbuhan dan produksi tanaman gambas terhadap pemberian Trichoderma sp. dan beberapa dosis pupuk kandang kotoran sapi menunjukkan hasil tidak berbeda nyata terhadap panjang buah rata-rata dan berat buah per tanaman. Respon pertumbuhan dan produksi tanaman gambas terhadap pemberian beberapa dosis pupuk kandang kotoran sapi menunjukkan pengaruh sangat nyata terhadap panjang tanaman dan diameter buah.

Tanaman yang diberi perlakuan $\mathrm{K}_{2}$ (pupuk kandang kotoran sapi dengan dosis 30 ton/ha) memiliki batang terpanjang $45,88 \mathrm{~cm}$. Tanaman terpendek diperoleh pada tanaman yang diberi perlakuan $\mathrm{K}_{0}$ (tanpa pupuk kandang kotoran sapi) yaitu $39,56 \mathrm{~cm}$. Tingginya pertumbuhan dan produksi tanaman gambas pada perlakuan pupuk kandang kotoran sapi 30 ton/ha menunjukkan bahwa pemberian pupuk kandang kotoran sapi dalam jumlah yang tepat ke dalam tanah dapat meningkatkan kadar hara di dalam tanah, tanaman pun tumbuh lebih baik.

Menurut Abdoellah (1996), takaran pupuk kandang yang sesuai akan mampu memperbaiki sifat tanah. Jasad mikro dan makro berperan dalam proses perombakan atau dekomposisi sehingga struktur tanah jadi lebih baik dan remah. Selanjutnya Rinsema (1993) menyatakan bahwa tanaman akan tumbuh subur bila hara yang dibutuhkannya tersedia dalam jumlah yang optimum. Menurut Suryana (2008), Rendahnya pertumbuhan tanaman gambas tanpa perlakuan pemberian pupuk kandang sapi disebabkan karena unsur hara yang tersedia di dalam tanah tidak mencukupi untuk merangsang pertumbuhan tanaman gambas.

Jumlah buah per tanaman yang diamati dalam penelitian ini menunjukkan bahwa tanaman yang memiliki jumlah buah terbanyak pada perlakuan $\mathrm{T}_{1} \mathrm{~K}_{2}$ (Trichoderma sp. $15 \mathrm{~g}$ dan pupuk kandang kotoran sapi dengan dosis 30 ton/ha) sebanyak 12,70 buah. Tanaman yang memiliki buah paling sedikit pada perlakuan ToKo yaitu 9,05 buah. Hal ini menunjukkan bahwa Trichoderma sp. dapat menyuburkan tanah. Hasil penelitian Esrita et al., (2011) menunjukkan bahwa semakin banyak Trichoderma $s p$. yang diberikan ke dalam tanah maka akar semakin baik pertumbuhan dan hasil tanaman gambas. Menurut Hanafiah (2005), jumlah total mikrobia dalam tanah digunakan sebagai indeks kesuburan tanah karena pada tanah yang subur jumlah mikrobianya tinggi.

Panjang buah rata-rata dan berat buah per tanaman yang diamati dalam penelitian ini menunjukkan perbedaan yang tidak nyata. Interaksi yang tidak nyata antara Trichoderma sp. dan beberapa dosis pupuk kandang kotoran sapi, disebabkan kemampuan Trichoderma sp. dalam mendekomposisi bahan organik serta sebagai agens hayati. Hal ini sesuai pernyataan (Suyamto, 2003 da;lam Siregar, 2018)) bahwa hasil tanaman sangat ditentukan oleh ketersediaan unsur hara, baik unsur hara makro maupun mikro. Respon pupuk kandang kotoran sapi juga lambat dalam menyediakan unsur hara bagi tanaman gambas, penghanyutan atau pengendapan unsur hara oleh air hujan.

Diameter buah yang diamati dalam penelitian ini menunjukkan tanaman yang memiliki diameter buah terbesar pada perlakuan $\mathrm{K}_{2}$ yaitu $3,86 \mathrm{~cm}$ dan tanaman dengan diameter terkecil pada perlakuan $\mathrm{K}_{0}$ yaitu $3,74 \mathrm{~cm}$. Pada perlakuan dengan dosis 30 ton/ha pupuk kandang kotoran sapi yang hasilnya sama dengan panjang tanaman. Semakin panjang tanaman maka semakin banyak sinar matahari yang diperoleh yang digunakan dalam proses fotosintesis. Banyaknya asimilat yang dihasilkan sangat tergantung pada kapasitas fotosintesis daun sebagai sumber penghasil asimilat, sedangkan asimilat yang tersedia kemudian didistribusikan ke berbagai organ pengguna yang terdapat pada tanaman.

Produksi buah/ha yang diamati dalam penelitian ini menunjukkan bahwa tanaman yang memiliki produksi buah/ha tertinggi adalah perlakuan $\mathrm{T}_{1} \mathrm{~K}_{2}$ yaitu 5,39 ton dan tanaman yang memiliki produksi buah/ha terendah dimiliki oleh perlakuan ToKo yaitu 3,78 ton. Hal ini bahwa pemberian Tricoderma sp. dapat membantu tanaman inang dalam menyerap unsur hara. Hal ini sependapat Menurut Subhan (2012) apabila cendawan 
Trichoderma telah menginfeksi akar tanaman inang, maka cendawan Trichoderma membantu tanaman induk/inang menyerap unsur hara tertentu terutama fosfat.

Pupuk kandang kotoran sapi juga sangat berperan dalam pertumbuhan dan hasil gambas. Hal ini disebabkan dengan pemberian pupuk kandang sapi 27 meningkatkan ketersediaan sejumlah unsur hara. Seperti dikemukakan oleh Mulyani dan Kartasapoetra (1998) bahwa pupuk kandang sapi selain mengandung unsur hara makro juga mengandung unsur hara mikro kesemuanya membantu menyediakan unsur hara bagi kepentingan pertumbuhan dan perkembangan tanaman

\section{KESIMPULAN}

Berdasarkan hasil penelitian yang telah dilakukan, maka dapat disimpulkan bahwa :

1. Pemberian Trichoderma sp. memberikan pengaruh terbaik terhadap jumlah buah pertanaman panjang buah rata-rata $(\mathrm{cm})$, dan produksi buah/ha (ton).

2. Pemberian pupuk kandang kotoran sapi 30 ton/ha memberikan pengaruh terbaik terhadap panjang tanaman $(\mathrm{cm})$, jumlah buah pertanaman panjang buah rata-rata $(\mathrm{cm})$, diameter buah (cm), dan produksi buah/ha (ton).

3. Interaksi antara pemberian Trichoderma sp. dan pupuk kandang kotoran sapi 30 ton/ha memberikan pengaruh terbaik terhadap jumlah buah pertanaman dan produksi buah/ha (ton).

\section{DAFTAR PUSTAKA}

Anis, S dan B.P Gayuh. 2014. Development Of Fusarium Disease Control Tecnology With Biological Agent In Mas (Luffa acutangula L. Roxb.) In Land Infected. Universitas Muhammadiyah Purwokerto. Purwokerto.

Badan Pusat Statistik. 2019. Produksi Tanaman Sayuran Menurut Kabupaten/ Kota dan Jenis Sayuran di Provinsi Sumatera Selatan. Palembang.

BPTP Jambi. 2010. Teknologi Budidaya Oyong(Luffa acutangula L. Roxb.) Badan Pengkajian Teknologi Pertanian Jambi. Jambi.

Dandge, V.S., SP. Rothe., and AS. Pethe. 2012. Antimicrobial activity andPharmacognostic
Study of (Luffa acutangula L. Roxb). Var amara on some deuteromycetes fungi. Int $\mathrm{J}$ of Sci Innovations and Discoveries. 2 (1): 191.

Davis. J.M. 1996. Loofa gourds The Permaculture Activist. 34:45-47.

Djazuli, M, dan M. Ismunadji, 1983. Pengaruh NPK terhadap Pertumbuhan Serapan Hara, dan Komposisi Senyawa Bahan Organik Ubi Jalar. Penelitian Pertanian Bogor. Pusat Penelitian dan pengembangan Tanaman Pangan. Vol. 3 (2): 76.

Dhashora, N., L.S. Chauhan., and N. Kumar. 2013. Luffa acutangula (Linn) Roxb. Var. Amara (Roxb.) A Consensus Review. Int J Pharm Bio Sci. 4(2):835-846.

Edi, S, dan J. Bobihe. 2010. Budidaya Tanaman Sayuran Gambas. Jambi (ID): Balai Pengkajian Teknologi Pertanian Jambi.

Esrita, B., Ichwan dan Irianto. 2011. Pertumbuhan dan Hasil Gambas(Luffa acutangula L Roxb). Pada Berbagai Bahan Organik dan Dosis Trichoderma sp. Jurnal Akta Agrosia 13 (2):37-4.

Gomez, K. A and A. A. Gomez. 1984. Statical Procedul For Agricultural Research.Second Edition. John Wiley and Sons. New York.

Hardjowigeno, S. 2007. IImu Tanah. Akademika Pressida. Jakarta.

Lingga, P. 2006. Petunjuk Penggunaan Pupuk. Penebar Swadaya Jakarta.

Noor, A dan R.D. Ningsih. 1998. Upaya Meningkatkan Kesuburan Dan Produktivitas Tanah Dilahan Kering. Dalam Prosiding Lokakarya Strategi Pembangunan Pertanian Wilayah Kalimantan. Instalasa Penelitian dan Pengkajian Teknologi Pertanian. Banjar Baru.

Nurtika, N dan N. Sumarni. 1992. Pengaruh Sumber Dosis dan Waktu Aplikasi Pupuk Kalium terhadap Pertumbuhan dan Hasil Tomat. Bul Penel. Hort., $\quad$ vol. 22, no. 1, pp. 96-101.

Poulton, J.L., RT. Koide and AG. Stephenson. 2011. Effects OF Trichderma Infection and 
Soil Phosphorus Availability On In-Vivo Pollen Performance In Lycopersi-Con Esculentum (Solanaceae). American J. Botany 1786-1793.

Purwantisari, S. 2009. Isolasi dan Identifikasi Cendawan Indigenous Rhizosfer Tanaman Kentang Dari Lahan Pertaniankentang Organik di Desa Pakis. Magelang. Jurnal BIOMA. ISSN:11 (2):45.

Rosewarne, G., SJ. Basker., SE. Smith., FA. Smith and DP. Schachtman. 1999. A Lycopersicon esculentum Phosphate Transporter (LePTI) Involved In Phosporus Uptake From A Trichoderma Fungus. New Phytologist 144, 507-516.

Rubatzky, V.E., dan M. Yamaguchi. 1997. Sayuran Dunia: Prinsip Produksi dan Giji Jilid Kedua. C Herison, Perjemah. Bandung (ID): Institut Teknologi Bandung.

Salisbury, F.B., dan C.W. Ross. 1995. Fisiologi Tumbuhan. Jilid I. Edisi IV. ITB, Bandung.
Setiawan, A. 2008. Memanfaatkan Kotoran Ternak. Penebar Swadaya. Jakarta.

Sukamto, 2007. Pemupukan Tanaman Sayuran. Jakarta.

Sumarni, N., R. Rosliana, dan A.S. Duriat. 2010. Pengolahan Fisik, Kimia, dan Biologi Tanah Untuk Meningkatkan Kesuburan Lahan dan Hasil Gambas. Balai Penelitian Tanaman Sayuran.

Triyanto, dan Sumantri. 2003. Makalah Lab. PHPT. Wilayah Semarang.

Wahyuno, D., Manohara dan Mulya. 2009. Peranan Organik Pada Pertumbuhan dan Daya Antagonisme Trichoderma Harzianum Dan Pengaruhnya Terhadap $P$. capsici. Pada Tanaman Lada. Jurnal Fitapatologi Indonesia 7:76-82.

Yuliarti, N. 2009. 1001 Cara Menghasilkan Pupuk Organik. Edl. Yogyakarta. 